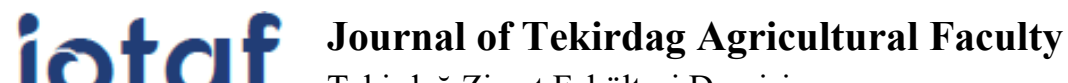

Tekirdağ Ziraat Fakültesi Dergisi

\section{Bakteriyel Kanser Ve Solgunluk Hastalığına Dayanıklı Ümitvar Domates Mutantlarında PR1 Geninin Dayanıklılık Mekanizmasındaki Rolü}

The Role of PRl Gene in Resistance Mechanism to Bacterial Canker and Wilting Disease in Promising Tomato Mutant Plants

\author{
Deniz KARABULUT ${ }^{1}$, Özer ÇALIŞ ${ }^{2 *}$
}

\section{$\ddot{\mathbf{O} z}$}

Domates Dünya'da ve Türkiye'de en çok üretilen ve tüketilen sebze bitkileri arasındadır. Domates bitkisi bu kadar çok üretilmesinin yanında yetiştiriciliği esnasında birçok fungal, bakteriyel ve viral hastalık etmenlerinin olumsuz etkilerine maruz kalmaktadır. Bu etmenlerden en önemlileri arasında bulunan bakteriyel kanser ve solgunluk hastalığına neden olan patojen domates bitkilerinde önemli ürün kayıplarına sebebiyet vermektedir. Hastalıkla mücadelede etkin bir yöntem dayanıklı çeşit geliştirmektir. Hastalığa dayanıklı kültür domates çeşitlerinin olmamas1 nedeniyle NCEBR3 kültür domates hattı ethyl methanesulfonate (EMS) kimyasal mutasyonuna uğratılarak M3-9 ve M3-15 mutant bitkileri hastalığa dayanıklı olarak bulunmuştur. Bu çalışmayla mutant bitkilerdeki dayanıklılığı sağlayan mekanizmalar arasında önemli bir rolü olan Patojenisite ile İlgili (PRI) geninin M3-9 ve M3-15 mutant dayanıklı bitkiler üzerindeki üretimini ortaya koymak için Real-Time PCR analizleri yapılmıştır. Dayanıklılık mekanizması içerisinde üretilen $P R 1$ geni ve bu genin kodladığı proteinler mutant bitkilerde inokulasyondan sonraki 5. güne kadar çok miktarda oluştuğu, buna karşın hassas NCEBR3 bitkilerinde PR1 geni ve onun kodladığ1 PR1 proteininin üretiminin kısıtlandığı bulunmuştur. Hassas orijinal NCEBR3 bitkilerinde $P R 1$ genin gecikmeli üretilmesi nedeniyle bakteriyel hastalık etmeni kolonize olurken dayanıklı M39 ve M3-15 bitkilerinde inokulasyondan itibaren üretilen $P R 1$ geni bakteriyel hastalık etmeninin kolonizasyonunu engellemektedir. Yapılan çalışmalar dayanıklılıktan sorumlu gen(ler)in altında bulunan $P R 1$ geni ve bu genin ürettiği PR1 proteinlerinin iki mutant bitkide dayanıklılı̆g sağladığını göstermektedir. Dayanıklılığı sağlayan gen(ler)in haritalanması ve sinyal yolaklarının aydınlatılması çalışmaları hala devam etmektedir. Dayanıklılık gen(ler)i klonlanmasıyla bakteriyel kanser ve solgunluk hastalığının genetik kontrolü mümkün olacaktır. Eldeki veriler bakteriyel kanser ve solgunluk hastalı etmeninin mücadelesinde en uygun yöntemin genetik olarak dayanıklı domates bitkileri üretmek olduğunu göstermektedir. Genetik olarak dayanıklı domates çeşitleri üretmek uzun soluklu bir süreç olup bu çalışmada elde edilen ümitvar domates çeşitleri ters genetik yöntemiyle oluşturulmuştur.

Anahtar Kelimeler: PR1 proteini, Real-Time PCR, moleküler, cDNA, patojen, genetik, RNA

\footnotetext{
1Deniz KARABULUT, Tarım ve Kırsal Kalkınmayı Destekleme Kurumu Muș İl Koordinatörlüğü, Hürriyet Caddesi Merkez, Muş Türkiye. E-mail: dkarabulut89@gmail.com (D) OrcID: 0000-0001-8701-7865.

${ }^{2}$ *Sorumlu Yazar/Corresponding Author: Özer ÇALIŞ, Akdeniz Üniversitesi Ziraat Fakültesi Bitki Koruma Bölümü Kampüs 07059 Konyaaltı, Antalya Türkiye. E-mail: ozercalis@akdeniz.edu.tr (D) OrcID: 0000-0002-7219-1219.

Atıf/Citation: Karabulut D., Çalış Ö. Bakteriyel kanser ve solgunluk hastalığına dayanıklı Ümitvar domates mutantlarında PR1 geninin dayanıkııık mekanizmasındaki rolü. Tekirdağ Ziraat Fakültesi Dergisi 19 (1) 120-131. 


\begin{abstract}
Tomato is among the most widely produced and consumed vegetable crops not only in Turkey but also in the world. During production of tomato, there are several fungal, bacterial and viral pathogens causing diseases on the valuable vegetable plant. Among them, bacterial canker and wilting pathogen makes significant crop losses in tomato plants. To control such bacterial pathogen, developing resistant varieties is an effective method where M39 and M3-15 mutant plants produced by ethyl methanesulfonate (EMS) chemical mutation from NCEBR3 cultivated tomato line. To date, there is neither resistant plant to bacterial canker and wilting pathogen nor effective biological control agents known. In this study, we aim to reveal accumulation of Pathogenicity Related-1 (PR1) gene which has an important role in resistant M3-9 and M3-15 mutant plants is working under resistant gene(s). Studies have unrevealed that the $P R 1$ gene encodes PR1 proteins in M3-9 and M3-15 mutant plants from inoculation to 5th days post inoculation, however, a little PR1 protein accumulation was detected in susceptible original NCEBR3 plants where PR1 protein was not enough to prevent bacterial canker and wilt pathogen. These results indicate resistant gene(s) have resistance mechanisms where PR1 gene and their encoded PR1 proteins accumulated in the two promising mutant plants. Resistance gene mapping studies have been continuing to clone resistance gene and its signaling pathways. The cloned resistance gene(s) will genetically enable to control such important bacterial pathogen causes bacterial cancer and wilting disease on tomatoes. All collected data encourage that the most appropriate method to control bacterial cancer and wilt disease is to develop genetically resistant tomato plants. Producing genetically resistant tomato varieties is long-term process, and the promising resistant tomato plants are created by reverse genetics.
\end{abstract}

Keywords: Pathogenesis related proteins, Real-Time PCR, molecular, cDNA, pathogen, genetic, RNA 


\section{Giriş}

Domates Dünya'nın birçok bölgesinde yüksek miktarda yetiştiriciliği ve tüketimi yapılan tarımsal anlamda en önemli bitkiler arasında bulunmaktadır. Birleşmiş Milletler Gıda ve Tarım Örgütü (Food and Agriculture Organisation of the United Nations: FAO) verilerine göre dünya genelinde 2019 y1lı itibarıyla domates 5.030.545 ha alanda 180.766 .329 ton üretilmiştir. Türkiye ise 181.488 ha alanda 12.841 .990 ton'luk domates üretimiyle Dünyada 3. sırada bulunmaktadır (Anonim, 2021a). Türkiye İstatistik Kurumu (TÜİK) verilerine göre ise Türkiye 2020 yılında 13.204.015 ton'luk bir üretim miktarına sahiptir (Anonim, 2021b).

Domates bitkileri açık ve kapalı üretim alanlarında yüksek üretim miktarına sahip olmasının yanında funguslar, bakteriler, virüsler ve viroidler gibi birçok biyotik hastalık etmenleri tarafından büyük miktarlarda zarara uğratılmaktadırlar. Bakteriyel patojenler arasında yer alan bakteriyel solgunluk ve kanser hastalığı etmeni Clavibacter michiganensis subsp. michiganensis $(\mathrm{Cmm})$ özellikle sıcaklığın ve nemin yüksek olduğu tropikal ve subtropikal bölgelerde domates üretimini kısıtlayan domatesin en önemli hastalıklarından birisidir. Patojen yaz aylarına nazaran kış aylarında toprakta canlılığını daha yüksek süre ile muhafaza etmektedir. Hastalık bitkilerde kanser ve solgunluk belirtileri göstererek domates bitkilerinin tamamen ölümüne sebebiyet vermektedir. Enfeksiyon doğrudan iletim demetleri dokusuna yerleşen inokulumdan kaynaklandığında sistemik enfeksiyon özellikle genç bitkilerde solgunluk belirtisi ile kendini göstermektedir. Yaşlı bitkilerde ise solgunluk belirtileri genç bitkilere oranla daha yavaş ve aşamalı olarak ortaya çıkmaktadır. Enfekteli gövdelerde iletim demetleri ilerleyen zamanlarda kahverengi görünüm almaktadır. Ayrıca patojenin floem ve parankima hücrelerine yayılması ile hastalığa yakalanan bitki gövde ve petiollerinde lekelenmeler, koyulaşarak bazı durumlarda da gövde üzerinde çatlaklar oluşmaktadır. Hastalık etmeninin bitki yüzeyindeki açıklıklar ile girişi gerçekleşmiş ise nekrozlar ve yaprak lekeleri gibi lokal belirtiler görülür. Bu lekelenmeler gittikçe artarak yaprak yüzeyinin büyük bölümünü kaplayarak yanmış bir görünüm oluşturmaktadır. Domates meyvelerinde ise patojen kuş gözü lekesi adı verilen lokal kahverengi belirtiler oluşturarak meyvenin pazar değerini düşürmektedir. (Agrios, 2007; Bergüzar ve ark., 2018; Çalış ve ark., 2013; Çetinkaya-Yı1dız, 2007).

Hastalık etmeninin bu derece yüksek öneme haiz olmasına rağmen günümüzde etkin kültürel, biyolojik ya da kimyasal bir mücadelesi bulunmamaktadır. Ancak antagonistik bakteriler, sodyum hipoklorit, laktik asit gibi alternatif uygulamaların özellikle domates tohumlarındaki hastalık gelişimi üzerinde sınırlandırıcı etkilere neden olarak bitkilerdeki patojen miktarının azaltılmasında etkili olduğu tespit edilmiştir. Hastalıkla mücadele de bitkiyi koruyucu amaçlı kimyasal uygulamalar yapılabilmektedir. Ancak bu uygulamalar çevre ve insan sağlı̆̆ üzerinde olumsuz etkilere yol açmaktadır. Bütün bu etkenler göz önüne alındığında hastalık etmeni patojenle kalıcı ve etkin bir mücadele yürütmek için en öncelikli konu dayanıklı bitki çeşidi geliştirilmesine yönelik çalışmalardır (Çalış ve ark., 2013; Karut ve ark., 2019).

$\mathrm{Cmm}$ patojeni konukçu uygunluğunu test ederek konukçu bitki üzerinde çoğalma faaliyetine başlamaktadır. Dolayısı ile moleküler mekanizmalarının anlaşılması, konukçu-patojen ilişkisinin ortaya konulmasıyla mümkündür. Konukçunun dayanıklılık gen(ler)inin kontrol ettiği hücre içerisindeki süper oksit patlamaları ve bunların yol açtığı hipersensitif hücre ölümü (HR), dayanıklılık gen(ler)inin aktive ettiği patojene özel proteinlerin (Pathogenesis related (PR) proteins) oluşumu ve sekonder metobolitlerin üretilmesi, patojene karşı oluşturulacak sistemik kazanılmış dayanıklılıkta görev alan salisilik asit, jasmonik asit ve etilen gibi bitki büyüme düzenleyicilerinin miktarındaki artışlar konukçu bitkide var olan dayanıklık gen(ler)i tarafından kontrol edilmektedir (Wang ve ark., 2007; Yun ve Loake, 2002; Robert-Seilaniantz ve ark., 2007; Alvarez, 2004).

PR1 genlerinin kodladığı proteinler bitkilerde patojenin enfeksiyonu, yaralanma, incinme, yüksek osmotik basınç gibi stres koşullarında oluşturularak patojenin saldırısını, yayılmasını ve çok yönlülügüunü sınırlandırmaktadırlar (Uknes ve ark., 1992). Hassas domates bitkilerinde klasik Mendel testlerinin ters bir şekli (reverse genetics) olan ethyl metanosulfonate (EMS) mutasyonu uygulaması ile gerçekleştirilen bakteriyel kanser hastalık etmenine karşı dayanıklı olan M3-9 ve M3-15 bitkilerinde meydana gelen ve dayanıklılığa neden olan genetik değişikliklerin belirlenmesi bu çalışmanın amacını oluşturmaktadır. Bu çalışma ile ümitvar dayanıklı bulunan M3-9 ve M3-15 dayanıklı bitkilerinin bakteriyel kanser hastalık etmenine karşı patojenesis ile ilgili gen(ler) ve bu gen(ler)in kodladığı protein üretimi araştırılmıştır. 


\section{Materyal ve Metot}

\subsection{Materyalin Temini}

Çalışmada kullanılan NCEBR3 domates hattı tohumları Mountain Horticultural Crops Research and Extension Center, North Caroline State University, USA'dan temin edilmiştir. Kullanılan NCEBR3 hattı North Caroline Early Blight Resistant 3 (NCEBR3) olarak bilinmekte olup yarı bodur sofralık domates genotipidir (Nash ve Gardner, 1988). Önceki yıllarda yapılan çalışmalarda NCEBR3 saf hat domates tohumlarının tek bazlık mutajen olan ethyl metanosulfonate (EMS, Sigma, Almanya) ile mutasyona uğratılması ve bitki genomu üzerindeki nükleotid sıralarında mutasyon ile sitozin (C) / guanin (G)'nin timin (T) / adenin (A) nükleotidlerine dönüşmesi sağlanarak $450 \mathrm{M} 2$ domates mutant bitkisinden 15 adet M2 mutant bitkisi hastalık etmeni Cmm2'ye karşı dayanıklı olarak bulunmuştur. Bu bitkilerden M3 populasyonlarının tohumları üretilmiş ve patojenisite testleri ile M3-9 ve M3-15 mutant familyalarındaki bitkiler $\mathrm{Cmm} 2$ patojenine karşı herhangi bir açılım göstermemiş̧ir (Çalış ve ark., 2013). EMS kimyasal mutajeni ile mutasyona uğratılmasıyla elde edilmiş olunan M3-9 ve M3-15 ümitvar dayanıklı mutantlarının tohumları ise Tokat Gaziosmanpaşa Üniversitesi Ziraat Fakültesi Bitki Koruma Bölümü Fitopatoloji Laboratuarında bulunan tohum koleksiyonundan sağlanmıştır.

\subsection{Bitkilerin yetiştirilmesi}

Çalışmada kullanılan domates tohumları 16 saat gündüz 8 saat gece uzunluğunda, $23 \pm 5^{\circ} \mathrm{C}$ sıcaklıkta ve $\% 60$ nispi nem koşullarındaki Tokat Gaziosmanpaşa Üniversitesi Ziraat Fakültesi Biyoteknoloji serasında içerisinde streril torf bulunan viyollere ekilmiştir. Viyollere ekilen domates tohumları düzenli aralıklarla sulanarak çimlenmeleri sağlanmıştır. Bitkiler 2-3 gerçek yapraklı döneme geldiklerinde içerisinde 1:1:1:1 oranında torf: perlit: toprak ve hayvan gübresinin $121^{\circ} \mathrm{C}$ 'de 15 dakika (dk) otaklav edilmesiyle hazırlanmış karışım içeren $20 \mathrm{~cm}$ çapında ve $30 \mathrm{~cm}$ derinlikteki saksılara dikilerek sera ortamında gelişmeye bırakılmış ve bitkilerin rutin bakımları yapılmıştır.

\subsection{Fitopatojen bakterilerin temini ve GYCA besi ortamında geliştirilmesi}

Clavibacter michiganensis subsp. michiganensis hastalık etmeninin virülensliği yüksek izolatı olan Cmm2 Akdeniz Üniversitesi Ziraat Fakültesi Bitki Koruma Bölümü Öğretim Üyesi Prof. Dr. Hüseyin BASIM'dan temin edilmiş̧ir. Patojenin çoğaltılması amacıyla Glikoz Yeast Carbonate Agar (GYCA) 5 gram (g) glucose, $5 \mathrm{~g}$ yeast extract, $40 \mathrm{~g}$ calsium carbonate ile oluşturulan karışıma 1 litre (L) oluncaya kadar saf su eklenmiş ve karışımın pH'1 7.2'ye $\mathrm{KOH}$ ya da $\mathrm{HCl}$ kullanılarak sabitlenmiş daha sonra karışıma 15 g Agar (Merck, Almanya) eklenerek besi ortamı 1 atmosfer (atm) basınçta $121^{\circ} \mathrm{C}^{\prime} \mathrm{de} 15 \mathrm{dk}$ otaklav edilerek hazırlanmıştır (Anonim, 2013). Otaklav işlemi tamamlanan besi ortamları $40^{\circ} \mathrm{C}$ sıcaklığa kadar soğutulduktan sonra steril kabin içerisinde steril cam petrilere dökülerek ortamların katılaşmaları sağlanmıştır. Cmm bakteri izolatları stok çözeltilerinden öze yardımı ile alınarak steril koşullarda hazırlanan ve cam petrilerde katılaşması sağlanan GYCA besi ortamlarına çizimleri yapılmış ve petriler streç film ile sarılarak $28^{\circ} \mathrm{C}$ 'deki inkübatörde 3 gün süre ile bekletilerek bakterilerin gelişmeleri sağlanmıştır.

\subsection{Cmm patojeninin test bitkilerine inokulasyonu}

İnokulasyonda NCEBR3, M3-9 ve M3-15 domates bitkilerinden 3'er adet olmak üzere toplamda 9 adet bitki kullanılmıştır. Bu deneme farklı zamanlarda 3 defa tekrarlanmıştır. Hastalık etmeni bakteri GYCA besi ortamında geliştirildikten sonra steril kürdan kullanılarak inokulasyon yapılmıştır. Her bitkiden inokulasyondan hemen sonra 0., 1., 2., 3., 4., 5., 7., 14. ve 21. günlerde 2'şer adet yaprak örneği alınmıştır. Alınan yaprak örnekleri sıvı azot içerisinde dondurularak $-80^{\circ} \mathrm{C}$ derin dondurucuda RNA izolasyonları yapılıncaya kadar saklanmıştır.

\subsection{Bitkilerden RNA izolasyonu ve complementary (c) DNA sentezi}

Bitkilerden alınan yaprak örneklerinden RNA izolasyonu için Qiagen RNA Easy Plant Mini Extraction (Qiagen, Almanya) kiti kullanılarak üretici firmanın önerdiği protokol takip edilmiştir. Elde edilen RNA örnekleri

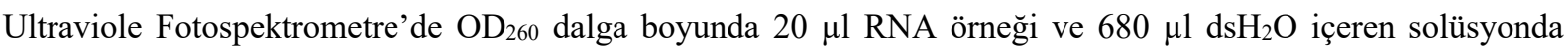
ölçümleri yapılarak tüm örneklerdeki RNA miktarları tespit edilmiş ve örneklerde belirlenen miktarlarda $\mathrm{ds}_{2} \mathrm{O}$ ilave edilerek Ependorf tüplerdeki RNA miktarları aynı oranda sabitlenmiştir. Daha sonra RNA'ların karşılı̆̆ı olan tamamlayıcı (complementary: c) cDNA sentezi için RNA örnekleri Takara Bio Inc şirketi tarafından geliştirilen ve Moloney Murine Leukemia Virus'ten elde edilen Reverse Transkriptaz (RTase) enzimi Prime Script Reverse 
Bakteriyel Kanser ve Solgunluk Hastalı̆̆ına Dayanıklı Ümitvar Domates Mutantlarında PR1 Geninin Dayanıklılık Mekanizmasındaki Rolü Transkriptase ile muamele edilerek örnekler cDNA'ya dönüştürülmüştür. Tek sarmal cDNA sentezi bu kit ile $42^{\circ}$ C sıcaklığında yapılabildiğinden enzimin çalışması için yüksek sıcaklığa gereksinim duyulmaması bu enzimin tercih edilme sebeplerinden birini oluşturmuştur. Çünkü yüksek sıcaklıkta RNA yapısında bozulma olmakta RNA özelliğini kaybetmektedir (Anonim, 2014a; Anonim, 2014b).

\subsection{Real Time PCR Mixture hazırlanmast ve analizlerin yapılmast}

Dünya genelinde Solaneceae familyasına ait bitki türlerinde ve model bitki Arabidopsis thaliana bitkisinde PR1 ve PR2 proteinlerinin tespiti ile ilgili yapılan çalışmalar incelenmiştir. Bu çalışmalarda kullanılan PR1 ve PR2 proteinlerinin sentezlenmesini sağlayan $P R 1$ ve $P R 2$ genlerine ait spesifik primerler Iontek firmasından temin edilmiştir. Bu primerler ile çalışmaya konu bitki DNA'ları klasik Polymerase Chain Reaction (PCR)'da 35 defa çoğaltılarak elektroforez jelde koşturulmuştur. Jel görüntüleme sisteminde bu kullanılan primerlerden 2 adet $P R 1$ genine ait primerler seçilmiştir. Önce seçilen primer çifti PCR ile çoğaltılıp elde edilen üründe bant oluşumu görülmüş ve Real-Time PCR çalışmaları bu primerler üzerinden yürütülmüştür. Çalışmada Xiao ve ark. (2003)'nın Arabidopsis thaliana bitkisinde kullandıkları PR1-Forward, 5' -AGA GGC AAC TGCA GAC TCA TAC AC3'; PR1-Reverse, 5' -AGC CTT CTC GCT AAC CCA CAT-3' primerleri kullanılmıştır. Ayrıca pozitif kontrol grubu olarak yine Xiao ve ark. (2003) tarafindan kullanılan 18S ribozomal DNA; 18S-Forward, 5'-CGT CCT AGT CTC AAC CAT AAA CGA T-3'; 18S-Reverse, 5'-GGT GCC AGC GGA GTC CTA T-3' primerleri kullanılmışırı. $P R 1$ geninin kodladığı PR1 proteinleri anti mikrobiyal aktiviteye sahip olup inokulasyondan sonra dayanıklı bitkiler tarafından üretilmekteyken bu çalışmada seçilen 18S ribozomal DNA tüm bitkilerde var olan standart DNA olarak kullanılmıştır.

Real-Time PCR'da boyar madde olarak Bio-Rad (Almanya) marka Universal SYBR Green Supermix kullanılmış olup her bir örnek için ds $\mathrm{H}_{2} \mathrm{O} 10 \mu \mathrm{l}$, SYBR Green SüperMix BioRad $12.50 \mu 1$, Primer Forward $10 \mu \mathrm{M}$ $0.25 \mu \mathrm{l}$, Primer Reverse $10 \mu \mathrm{M} 0.25 \mu \mathrm{l}$ ve cDNA $2.00 \mu \mathrm{l}$ eklenerek toplam da $25.00 \mu \mathrm{l}$ Real-Time PCR karışımı hazırlanmıştır (Anonim, 2014c). Çalışmalarda PR1 primeriyle hazırlanan 40 örnek ve 18S ribozomalDNA (rDNA) ile hazırlanan 40 olmak üzere toplamda 80 adet örnek PCR karışımı için 0.2 ml'lik PCR Script tüplerinin her birine $23 \mu 1$ olarak ilave edilmiş daha sonra ise sırasıyla cDNA örnekleri bu karışımlara eklenmiştir. PCR işlemi Stratagene marka Mx3000p model Real-Time PCR cihazında gerçekleştirilerek başlangıç (denaturation) $94^{\circ} \mathrm{C}$ 'de 5 dakika, 40 döngü (cycles) boyunca $94^{\circ} \mathrm{C}^{\prime}$ de $1 \mathrm{dk}, 55^{\circ} \mathrm{C}$ 'de 45 saniye, $72^{\circ} \mathrm{C}^{\prime} \mathrm{de} 45$ saniye, final uzama (extension) $72^{\circ} \mathrm{C}$ 'de $10 \mathrm{dk}$ ve Store $25^{\circ} \mathrm{C}$ sonlandırma adımlarından oluşan program kullanılmıştır (Anonim, 2014c).

\section{Araştırma Sonuçları ve Tartışma}

$\mathrm{Bu}$ çalışma ile dayanıklılık mekanizmasında aktif rol oynayan PR1 proteinini kodlayan RNA ile birlikte tüm bitkilerin sahip olduğu $18 \mathrm{~S}$ ribozomal DNA'nın kontrol ettiği protein miktarı pozitif kontrol olarak RT-PCR' da ölçümlenmiştir. $\mathrm{Bu}$ amaçla $\mathrm{Cmm} 2$ bakteri izolatına karşı mutant dayanıklı ve orijinal hassas domates bitkilerindeki PRl geninin kodladığı protein miktarının ölçümlenmesi gerçekleştirilmiştir. SYBR Green boyası başlangıçta az miktarda bulunan DNA'ya bağlanmakta, her bir döngüde DNA miktarı 2 kat artmakta ve buna bağlı olarakta floresan miktarı artış göstermektedir. Bu şekilde floresan boyanın doğrusal olarak okunabildiği döngüye threshold $(\mathrm{Ct})$ denilmektedir. Bu noktada örnek miktarının nispi konsantrasyonu ile hedeflenen DNA miktarı arasındaki fark floresan boya ile doğru olarak tespit edilmektedir. Bir başka ifadeyle $\Delta \mathrm{Ct}=\mathrm{Ctö̆rnek}-\mathrm{Ct}_{\text {referans }}$ denklemi ile DNA miktarı kantitatif olarak belirlenebilmektedir (Dorak, 2006).

Yapılan çalışmalarda PR1 geninin dayanıklı ve hassas bitkilerdeki oluşum miktarları nispi olarak PR1 primerinin kullanıldığı kantifikasyonun Ct değerleri ile pozitif kontrol olarak 18S rDNA'nın kullanıldığı kantifikasyonun $\mathrm{Ct}$ değerlerinin baz alındığı $\Delta \mathrm{Ct}$ değerlerinin her örnek için ayrı ayrı hesaplanmasıyla Şekil 1 . oluşturulmuştur. RT-PCR çalışmalarında M3-9 ve M3-15 dayanıklı mutant domateslerinde inokulasyondan itibaren 0. günden 3. güne kadar Cmm2'ye dayanıklı M3-9 ve M3-15 domates bitkilerinde PR1 proteininin üretimini tetikleyen $P R 1$ geni oransal anlamda hassas NCEBR3 bitkisine göre 2-6 kat daha yüksek seviyelerde oluşmaktadır (Şekil 1.). Bakteriyel hastalık etmeninin bitkilerdeki kolonizasyonu boyunca yüksek miktarda PR1 proteini dayanıklı mutant M3-9 ve M3-15 bitkilerinde oluşturulmaktadır (Şekil 1.). Bakteriyel hastalık etmeninin kolonizasyonundan sonra (4. gün) özellikle hassas NCEBR3 bitkilerinde de $P R 1$ genlerinin kodladığı PR1 protein üretiminde ciddi artışlar meydana gelmektedir (Şekil 2.). 


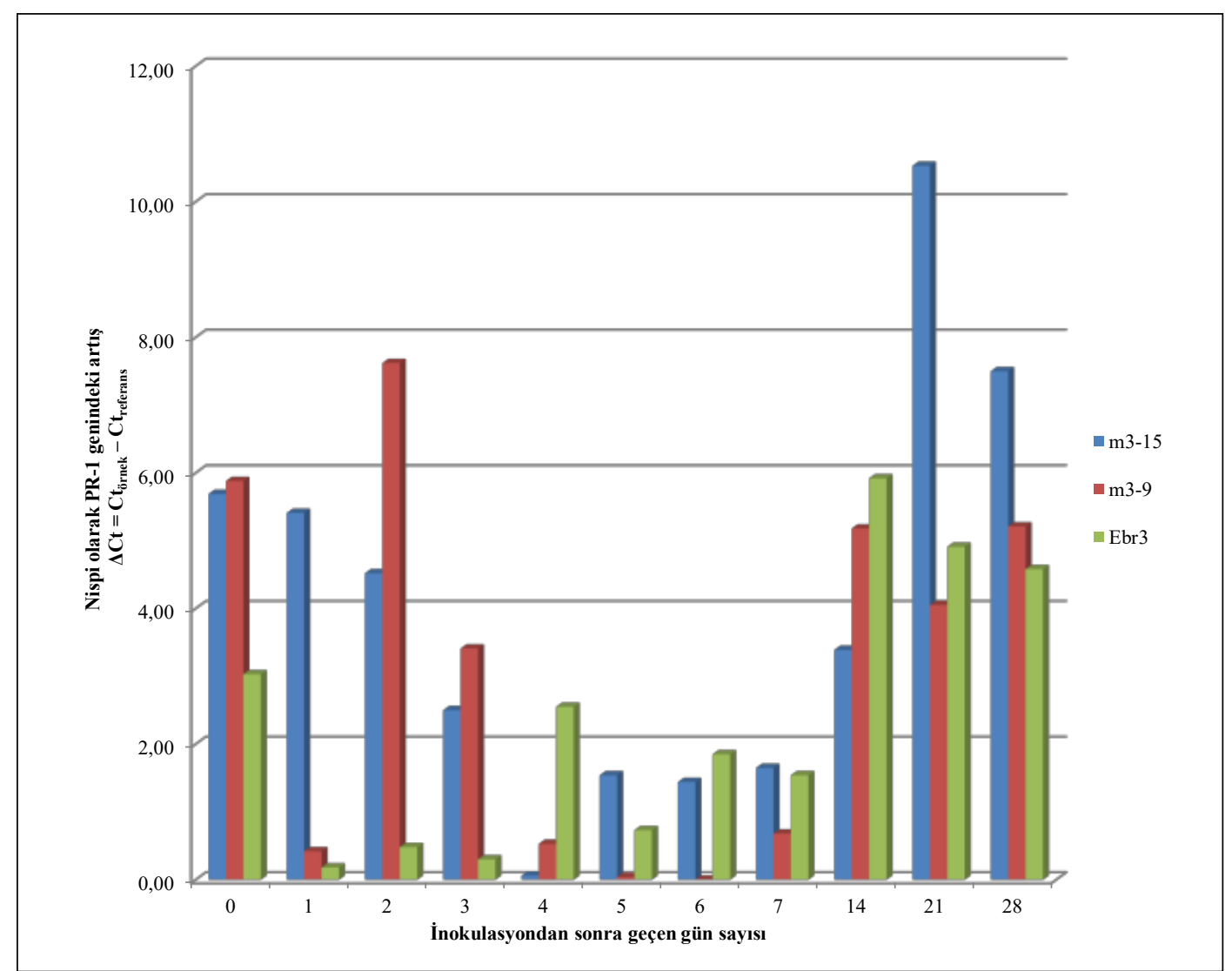

Figure 1. Relative quantification of PR1 gene in resistant and susceptible plants after Cmm2 inoculation.

Şekil 1. Cmm2 ile inokulasyonu takiben dayanıklt ve hassas bitkilerde oluşan PR1 geninin nispi olarak kantifikasyonu

Ancak hastalık etmeni bakteri bu süre zarfında hassas bitkilerde kolonizasyonunu tamamlamış ve bitki dokularında yayılmaya başladığı için hassas orijinal NCEBR3 bitkilerindeki bu PR proteinlerinin artışı bakteriyel patojeni sınırlamaya yeterli olmaktadır (Şekil 4). Bir başka ifadeyle hassas orijinal bitkilerde gecikmeli üretilen PR1 proteini patojenin yayılımını sınırlandıramamaktadır. Oysaki ümitvar dayanıklı mutant domates bitkilerinde hastalık inokulasyonunun ilk anından itibaren dayanıklılık genleri altında çalışan $P R 1$ geni yüksek miktarda PR proteinini üretmektedir (SSekil 1). Böylece PR1 proteini bakteriyel inokulasyondan itibaren $\mathrm{Cmm} 2$ patojenini sinırlamaktadır. PR1 proteinleri bakteriyel patojenin konukçu hücrelerine kolonizasyonunu engellemekte ve ölçümlemenin gerçekleştirildiği 21. günde M3-15 bitkilerinde hassas NCEBR3 bitkilerine göre 2 kattan fazla üretildiği anlaşılmaktadır (Şekil 1). PR1 proteinlerinin inokulasyondan sonra ani ve yüksek miktarda oluşturulması $\mathrm{Cmm} 2$ bakteriyel hastalık etmenini sınırlamaktadır (Şekil 2 ve 3). Fakat hassas NCEBR3 orijinal bitkilerindeki gecikmeli gerçekleşen yüksek PR1 protein oluşumları Cmm2 patojeninin kolonizasyonunu sinırlamamaktadır. Çalışmada dayanıklı M3-15 mutant bitkilerinde inokulasyondan sonra 21. ve 28. günlerde hala PR1 proteinin yüksek miktarda üretiliyor olması dayanıklılığın lokal reaksiyondan sistemik reaksiyona geçtiğini göstermektedir.

Pozitif kontrol olarak kullanılan 18S rDNA proteinleri inokulasyondan itibaren 21 gün boyunca her zaman aynı miktarda ölçümlenmekte olup bitkilerdeki miktarı değişim göstermemektedir (Şekil 4 ve 5). Tüm canlı hücrelerinde bulunan $18 \mathrm{~S}$ rDNA hücre nükleusu, ribozomlarda, mitokondri ve kloroplastlarda bulunan ribozomal RNA (rRNA) içerisinde var olduğu için çalışmada pozitif kontrol olarak kullanılmıştır. Tıpkı $P R 1$ geninde olduğu gibi rDNA'da belirtilen örneklerden izole edilen RNA'nın reverse trankriptaz enzimi ile üretilen cDNA içerisinde bulunmaktadır. Üretilen cDNA içerisindeki PR1 ve rDNA proteinlerinin miktarları RT-PCR ile aynı anda özel SYBR green boyası ile ölçümlendiği için rDNA ile PR1 protein miktarları mukayese edilerek kantifikasyon sağlanmıştır. 


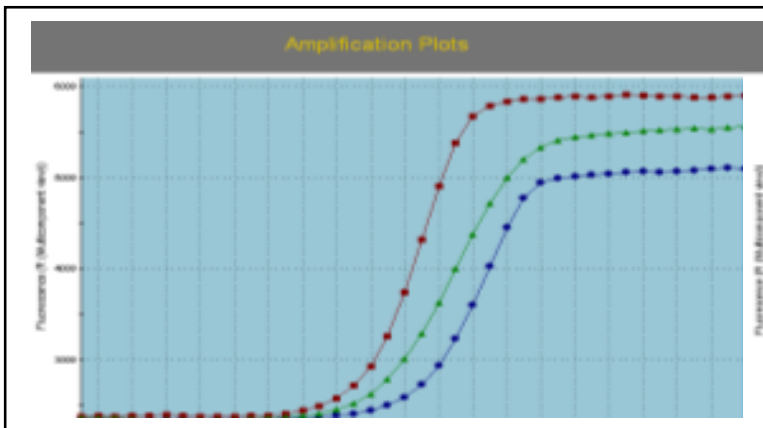

a) PR1 primer ile Real-Time PCR analizi 0.gün DPI ( mavi: EBR3, kırmızı: M3-9, yeşil: M3-15)

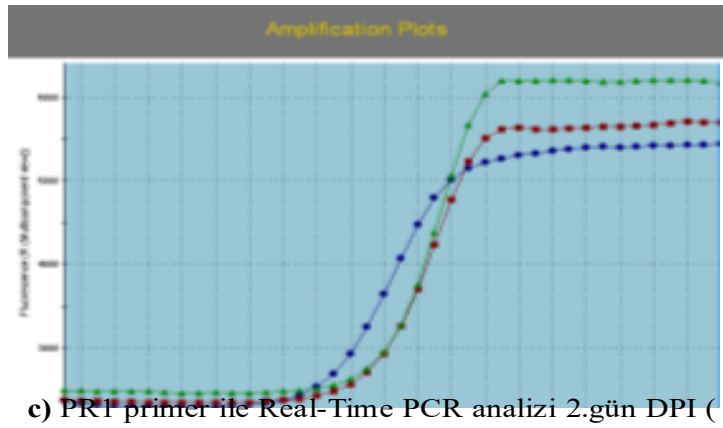
mavi: M3-15 , kırmızı: EBR3, yeşil: M3-9)

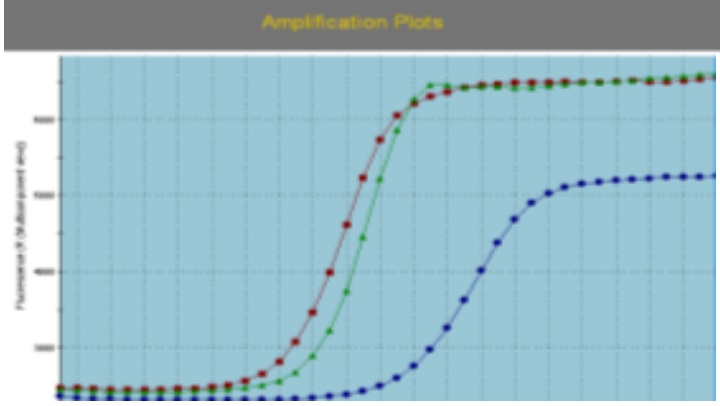

e) PR1 primer ile Real-Time PCR analizi 4.gün DPI ( mavi: EBR3, kırmızı: M3-9, yeşil: M3-15)

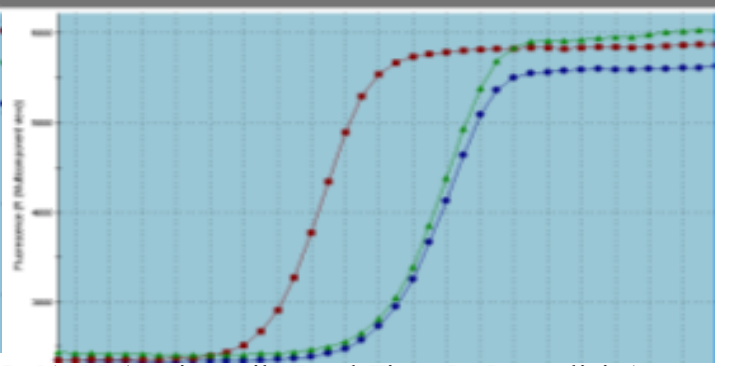

b) PR1 primer ile Real-Time PCR analizi 1.gün DPI ( mavi: EBR3, kırmızı: M3-9, yeşil: M3-15)

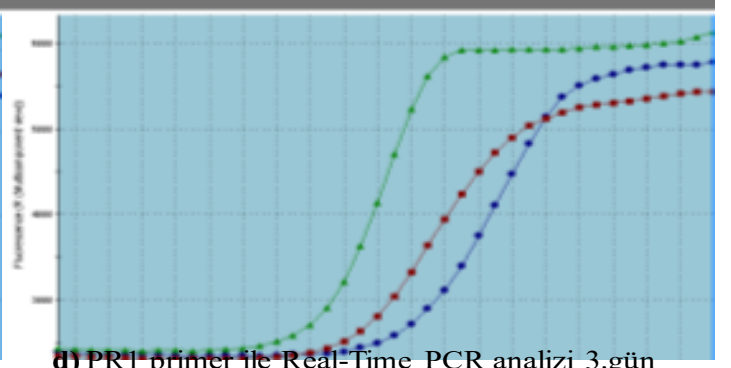

(ấl-Time PCR analizi 3.gü DPI ( mavi: EBR3, kırmızı: M3-9, yeşil: M3-15)

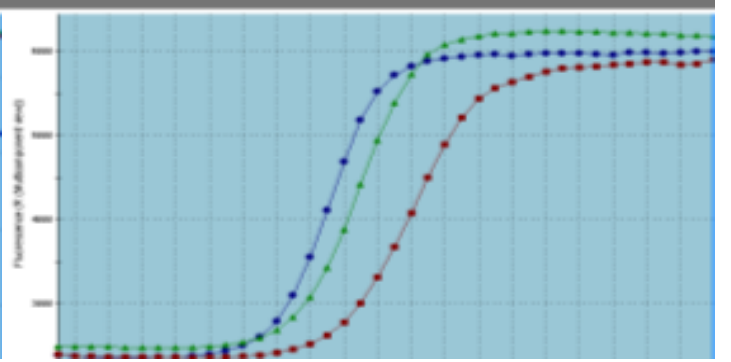

f) PR1 primer ile Real-Time PCR analizi 5.gün DPI ( mavi: M3-9, kırmızı: M3-15, yeşil: EBR3)

Figure 2. Real-Time PCR analyze results with PR1 primers. Şekil 2. PR1 primerleri ile Gerçek Zamanlt-PCR analiz sonuçları 


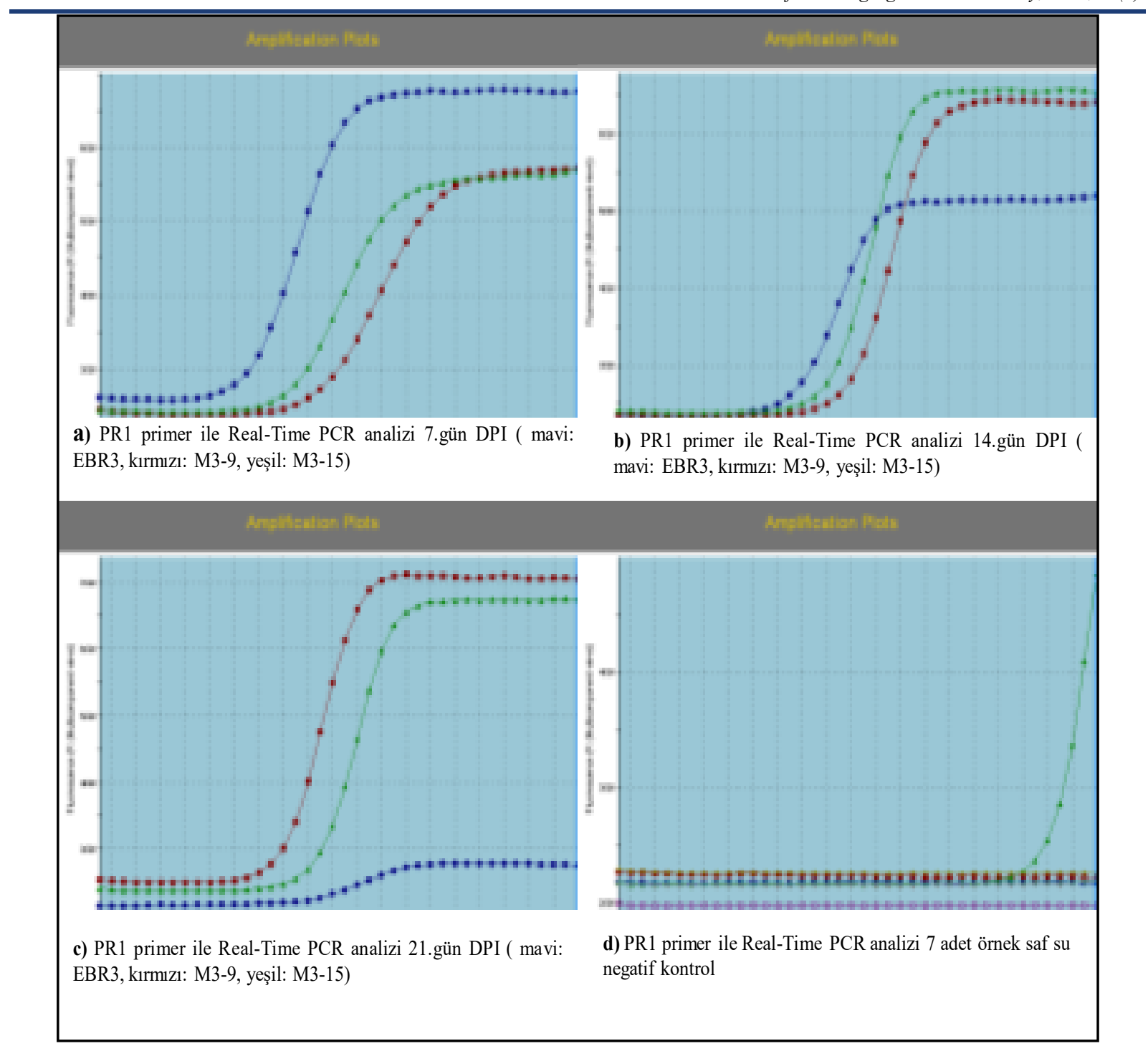

Şekil 3. PR1 primer ile Gerçek Zamanlı-PCR analiz sonuçları

Figure 3. Real-Time PCR analyze results with PR1 primers. 


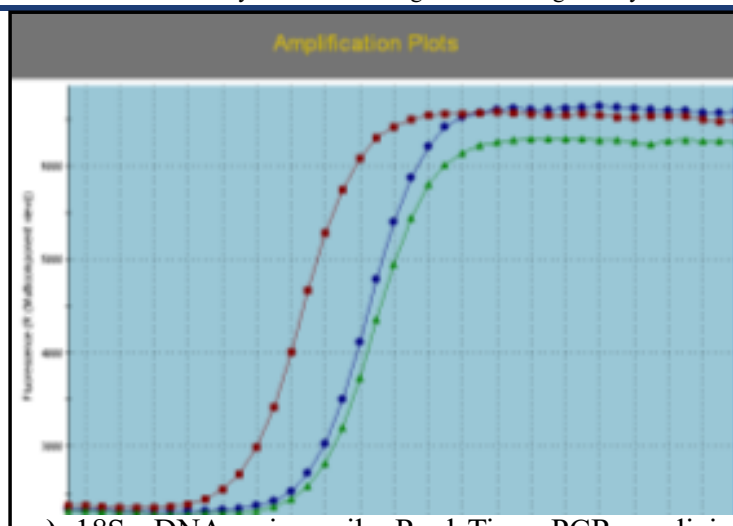

a) $18 \mathrm{~S}$ rDNA primer ile Real-Time PCR analizi 0.gün DPI ( mavi: EBR3, kırmızı: M3-9, yeşil: M315)

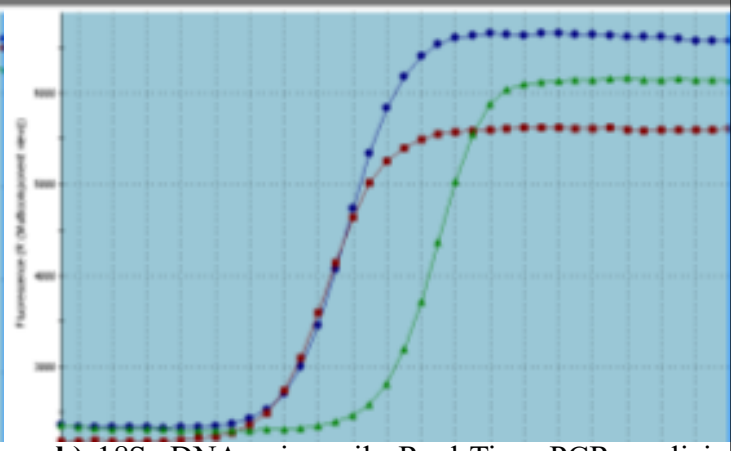

b) $18 \mathrm{~S}$ rDNA primer ile Real-Time PCR analizi 1.gün DPI ( mavi: EBR3, kırmızı: M3-9, yeşil: M3-15)

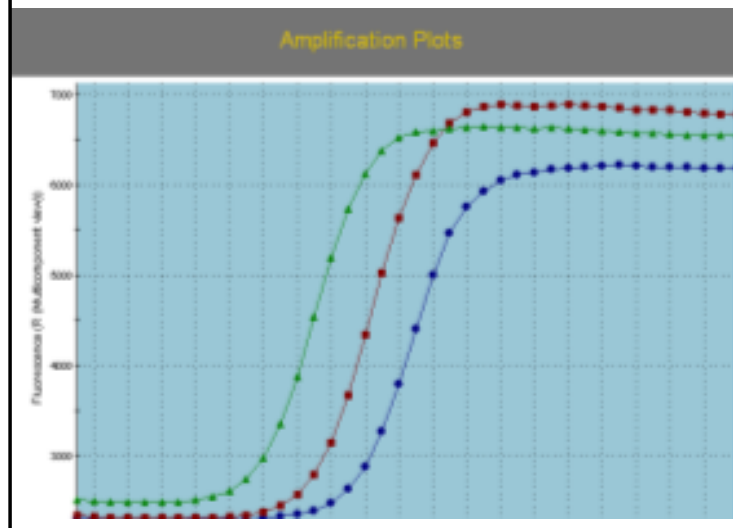

c) $18 \mathrm{~S}$ rDNA primer ile Real-Time PCR analizi 2.gün DPI ( mavi: M3-15, kırmızı: EBR3, yeşil: M39)

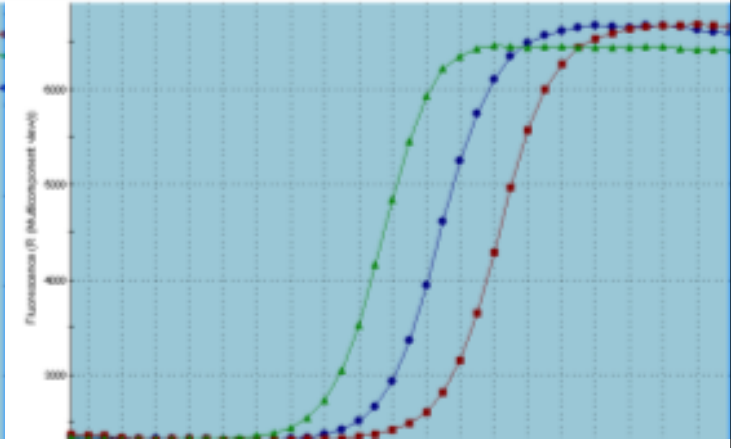

d) $18 \mathrm{~S}$ rDNA primer ile Real-Time PCR analizi 3.gün DPI ( mavi: EBR3, kırmızı: M3-15, yeşil: M3-9)

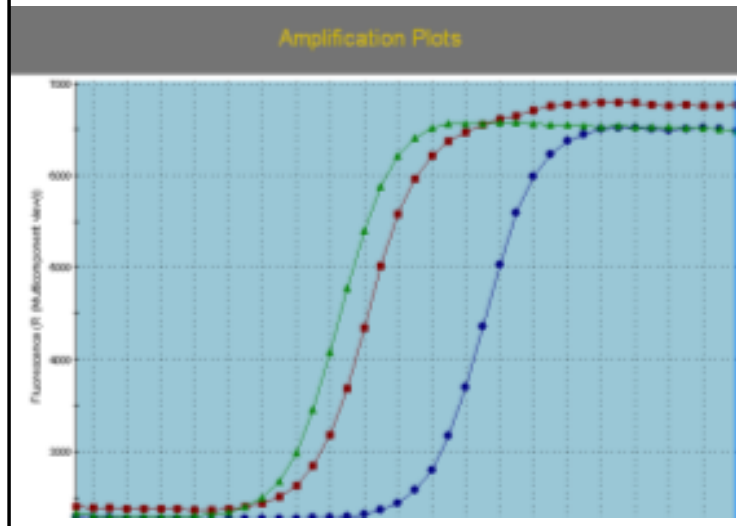

e) $18 \mathrm{~S}$ rDNA primer ile Real-Time PCR analizi 4.gün DPI ( mavi: EBR3, kırmızı: M3-9, yeşil: M315)

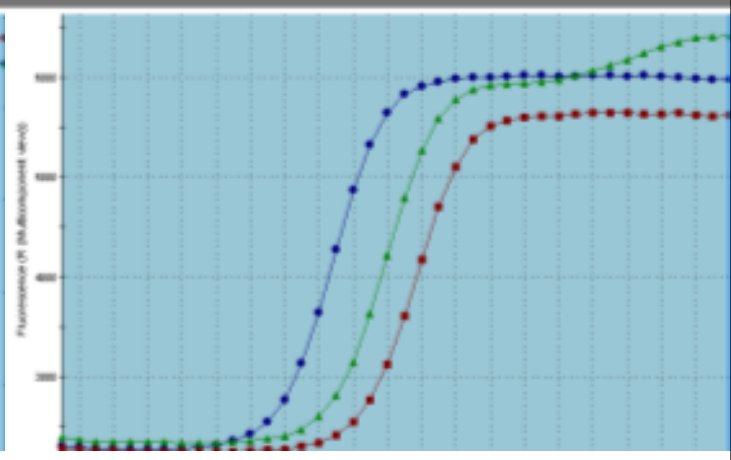

f) $18 \mathrm{~S}$ rDNA primer ile Real-Time PCR analizi 5.gün DPI ( mavi: M3-9, kırmızı: M3-15, yeşil: EBR3)

Şekil 4. 18S rDNA primer ile Gerçek Zamanlt-PCR analiz sonuçlart

Figure 4. Real-Time PCR analyze results with $18 S$ rDNA primers. 


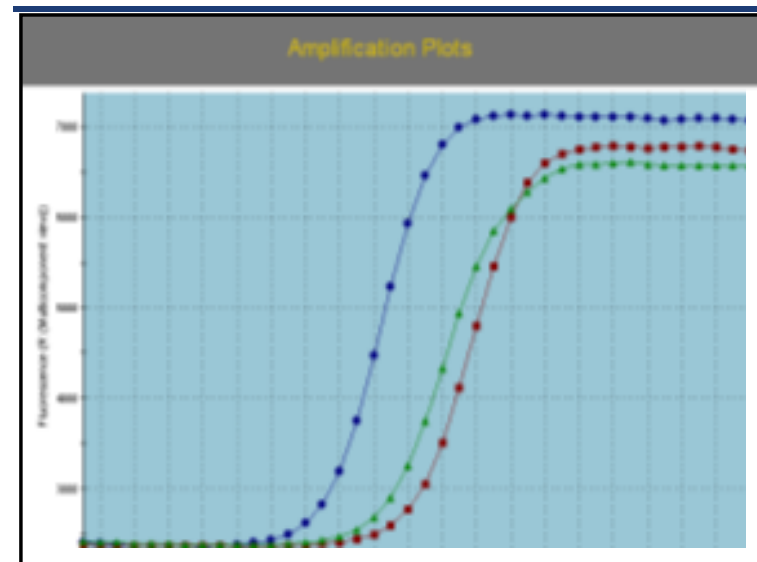

a) $18 \mathrm{~S}$ rDNA primer ile Real-Time PCR analizi 7.gün DPI ( mavi: EBR3, kırmızı: M3-9, yeşil: M315)

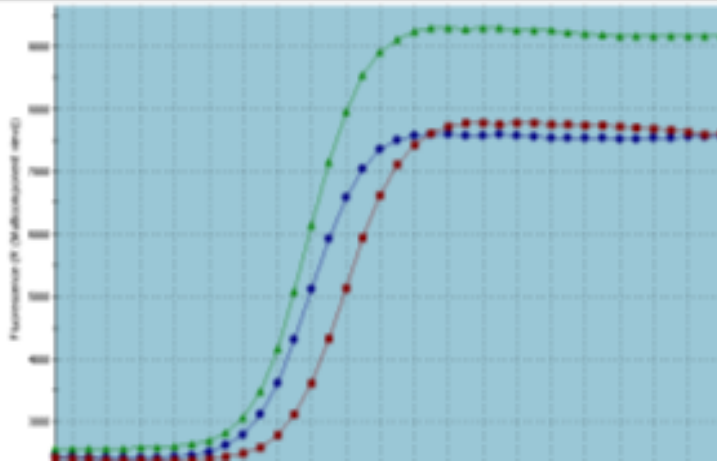

b) $18 \mathrm{~S}$ rDNA primer ile Real-Time PCR analizi 14.gün DPI ( mavi: EBR3, kırmızı: M3-9, yeşil: M3-15)

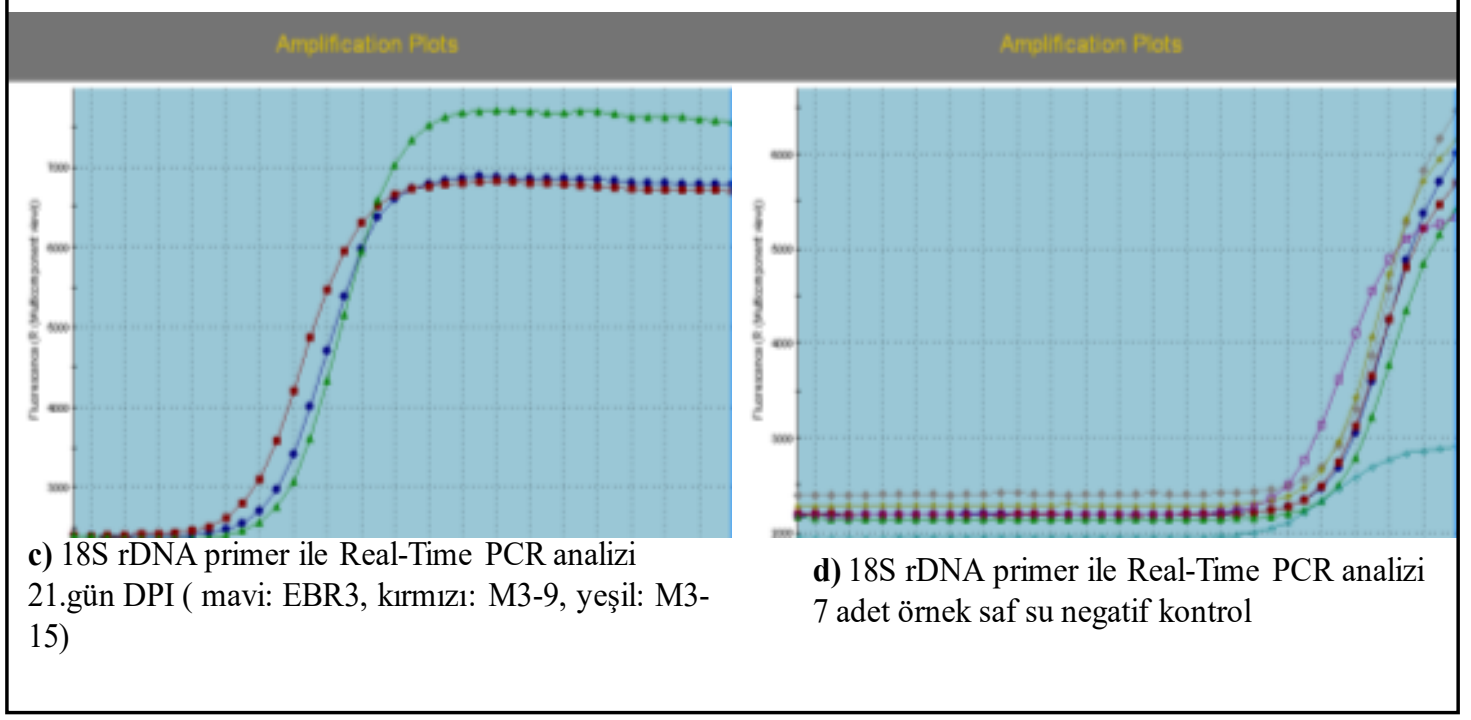

\section{Şekil 5. 18S rDNA primer ile Gerçek Zamanlt-PCR analiz sonuçlart}

Figure 5. Real-Time PCR analyze results with $18 S$ rDNA primers.

\section{Sonuç}

Gerçekleştirilen bu çalışma ile PR1 genlerinin kodladığ 1 PR1 proteinlerinin dayanıklı M3-9 ve M3-15 mutant bitkilerinde hızl, etkin ve spesifik olarak oluştuğu ortaya konmuştur. Hassas orijinal NCEBR3 bitkilerinde ise PR1 proteinlerinin oluşumu ancak inokulasyondan sonraki 4. günden sonra gerçekleşmektedir. Belirtilen bu süreye kadar konukçu hücrelerinden beslenerek hücreler arası bölgede kolonize olan ve hıla çoğalan bakteriyel $\mathrm{Cmm}$ patojen izolatlarını PR1 proteini kontrol edememektedir. Buna karşın ümitvar dayanıklı M3-9 ve M3-15 mutantlarında dayanıklılık gen(ler)i tarafından kontrol edilen savunma mekanizmasının bulunduğunu göstermektedir. Benzer sonuçlar Arabidopsis thaliana model bitkisinde kabak ve domates külleme hastalık etmenlerini kontrol eden RPW8 geninin kodladığ1 PR1 proteinlerinde de bulunmuştur (Xiao ver ark., 2005). Özellikle bu çalışmalarda PR3 (chitinase) ve PR5 (tomatin benzeri: thaumatin like) enzimatik aktiviteye sahip proteinlerin inokulasyondan hemen sonra RPW8 geni içeren Arabidopsis bitkilerinde oluşmaya başladığı ve inokulasyondan sonraki 4. günde hassas bitkilerdeki PR3 ve PR5 protein seviyelerinin dayanıklı bitkilerdeki seviyeden daha fazla olduğu bulunmuştur (Xiao ve ark., 2001; Xiao ve ark., 2003; Xiao ve ark., 2005).

Cmm2 hastalık etmenine karşı dayanıklı M3-9 ve M3-15 domates bitkilerinden elde edilen bitki ekstraktları Yüksek Basınçlı Sıvı Kromotografi (HPLC) sisteminde karşılaştırmalı analizleri yapılarak klorjenik asit ve rutin hidratın dayanıklı bitkilerde hassas NCEBR3 bitkilerine göre sırasıyla 6.7 ve 13 kat daha yüksek oluştuğu bulunmuştur. Yapılan çalışmada bulunan klorjenik asit ve rutin hidrat kimyasallarının artışı Bayan (2011) ve bu çalışmadan elde edilen PR1 proteinlerinin dayanıklı mutant bitkilerinde hızlı ve aniden üretilmesi ile örtüşmektedir. 
$\mathrm{Bu}$ durum bitkilerde dayanıklılık genleri tarafından üretilen sekonder metabolitler ve patojenle ilgili özel proteinlerin, bakterilerin inokulasyonundan hemen sonra devreye girdiğini göstermektedir. Nitekim Osbourne (2010a; 2010b)'un çalışmalarında dayanıklılık geni tarafından kontrol edilen sekonder metabolitlerin gen kümeleri tarafından kontrol edildiğini ve bu gen kümelerinin dayanıklılık geni tarafından yönetildiğini ortaya koymaktadır. Bu öngörüye paralel olarak gerek Çalış ve ark. (2012) 'nın M3-9 ve M3-15 bitkilerindeki kimyasal sekonder metabolitlerdeki artış gerekse bu çalışmada ortaya konan PR1 proteinlerindeki artışı kontrol eden gen(ler)in varlığını işaret etmektedir. Bir diğer ifadeyle M3-9 ve M3-15 bitkilerinde dayanıklılığı kontrol eden genler savunma mekanizmasını aktive ederek sekonder metabolit diye bilinen kimyasal maddeler ile patojene karşı özel üretilen PR1 proteinlerini oluşturmaktadırlar.

Halen devam eden çalışmalar ile M3-9 ve M3-15 bitkilerindeki dayanıklılık gen(ler)i ilginç bir şekilde aynı yerde haritalanmış olup bunların altında PR1 proteini ve sekonder metabolitlerin üretilmesini kontrol eden dayanıklılık gen(ler)inin yapılarının bulunduğu anlaşılmaktadır. Dayanıklılık genlerinin haritalanma çalışmalarının yapıldığı kromozom üzerinde 30 kadar dayanıklılık geninin olduğu belirlenmiş̧tir (Özer Çalış, Yayımlanmamış Bilgi).

\section{Teşekkür}

Bu çalışma Tokat Gaziosmanpaşa Üniversitesi tarafindan TOGÜBAP.2013/117 Nolu Araştırma Projesi olarak desteklenmiştir. 


\section{Kaynakça}

Agrios, G. N. (2007). Plant Pathology. Fifth Edition Elvesier Academic Press, London

Alvarez, A. M. (2004). Integrated approaches for detecion of plant pathogenic bacteria and characterization of a codominant marker linked to root-knot nematode resistance and diagnosis of bacterial diseases. Annal Reviews of Phytopathology 42: 339-366

Anonim (2021a). Food and Agriculture Organization of the United Nations (FAO), http://www.faostat.fao.org, (Erişim tarihi: 24.02.2021)

Anonim (2021b). Türkiye İstatistik Kurumu (TÜİK), http://www.tuik.gov.tr, (Erişim tarihi: 24.02.2021)

Anonim (2013). Plate Count Agar Tryptone Glucose Yeast Agar Protocol, http://www.oxoid.com/UK /blue/proddetail/proddetail.asp?pr=C $\underline{\mathrm{M} 0325 \& \mathrm{cat}=\& \mathrm{sec}=1}$ (Erişim tarihi: 18.11.2013).

Anonim (2014a). Qiagen Rneasy Plant Mini Kit Quick Start Protocol, http://www.qiagen.com/handbooks, (Erişim tarihi: 16.02.2014)

Anonim (2014b). Takara Bio Inc. Primescript Reverse Transkriptase Protocol, http://www.clontech.com/takara/NL/Products, (Erişim tarihi: 08.03.2014).

Anonim (2014c). Bio-Rad SYBR Green Real-Time PCR Mixture Preparation and Thermal Cycling Protocol, http://www.bio-rad.com, (Erişim tarihi: 08.09.2014).

Bayan, Y. (2011). Domates bakteriyel kanser hastalığl (Clavibacter michiganensis subsp. michiganensis)'na dayanıkl ve hassas bitkilerde fenolik maddelerin araştırılması. (Yüksek Lisans Tezi) Gaziosmanpaşa Üniversitesi Fen Bilimleri Enstitüsü, Tokat

Bergüzar, S., Yanar, Y. ve Aysan Y. (2018). Tokat ilinde domates bakteriyel solgunluk hastalığ'nın (Clavibacter michiganensis subsp. michiganensis) epidemiyolojisi. Tekirdă̆ Ziraat Fakültesi Dergisi 15(03) 9-16

Çalış, Ö., Bayan, Y. ve Çelik, D. (2012). Characterization of resistant tomato mutants to bacterial canker disease. African Journal of Biotechnology Vol 11, No:32

Çalış, Ö., Saygı, S., Çelik, D. ve Bayan, Y. (2013). Domates bakteriyel kanser ve solgunluk hastalığına dayanıklılık ve ters genetik. Akdeniz Üniversitesi Ziraat Fakültesi Dergisi 26(1): 5-10

Çetinkaya-Yıldız, R. (2007). Domates bakteriyel solgunluk hastalı̆̆ etmeni (Clavibacter michiganensis subsp. michiganensis (smith) davis et. al.) 'nin tanılanması ve bitki büyüme düzenleyici rizobakteriler ile biyolojik mücadele olanaklarının araştırılması.(Doktora Tezi) Çukurova Üniversitesi Fen Bilimleri Enstitüsü, Adana

Dorak, M. T. (2006). Real-Time PCR. Taylor and Francis Group MPG Books Limited, Cornwall

Karut, Ş. T., Horuz, S. ve Aysan, Y. (2019). Domates bakteriyel kanser ve solgunluk hastalı̆̆1 etmeni Clavibacter michiganensis subsp. michiganensis' in tohumda aranması ve farklı tohum uygulamalarının hastalık gelişimi üzerine olan etkisinin belirlenmesi. Tekirdağ Ziraat Fakültesi Dergisi 16(3) 285-296

Nash, A. F. ve Gardner, R. G. (1988). Tomato early blight resistance in a breeding line derived from Lycopersicon hirsutum P. I. 126445. Plant Disease 72: 206-209

Osbourn, A. (2010a). Secondary metabolic gene clusters: evolutionary toolkits for chemical innovation. Trends in Genentics 26: 449-457

Osbourn, A. (2010b). Gene clusters for secondary metabolic pathways: an emerging theme in plant biology. Plant Physiology 154: 531-535

Robert-Seilaniantz, A., Navarro, L., Bari, R. ve Jones, J. D. G. (2007). Pathological hormone imbalances. Current Opinion in Plant Biology 10: $372-379$

Uknes, S., Mauch-Mani, B., Moyer, M., Potter, S., Williams, S., Dincher, S., Chandler, D., Slusarenko, A., Ward, E. ve Ryals, J. (1992). Acquired resistance in Arabidopsis. American Society of Plant Physiologists The Plant Cell 4: 645-656

Yun, B. W. ve Loake, G. J. (2002). Plant defence responses: current status and future exploitation. Journal of Plant Biotechnology 4:1-6

Wang, W., Devoto, A., Turner, J. G. ve Xiao, S. (2007). Exression of the membrane-associated resistance protein RPW8 enhances basal defence against biotrophic pathogens. Molecular Plant-Microbe Interactions 20: 966-976

Xiao, S., Ellwood, S., Calis, O., Patrick, E., Li, T., Coleman, M. ve Turner, J. G. (2001). Broad- Spectrum mildew resistance in Arabidopsis thaliana mediated by RPW8. Science 5501: 118-120

Xiao, S., Brown S., Patrick, E., Brearley, C. ve Turner, J. G. (2003). Enhanced transcription of the Arabidopsis disease resistance genes RPW8.1 and RPW8.2 via a Salicylic Acid dependent amplification circuit is required for hypersensitive cell death. American Society of Plant Biologists The Plant Cell 15: 33-45

Xiao, S., Calis, O., Patrick, E., Zhang, G., Charoenwattana, P., Muskett, P., Parker, J. E. ve Turner, J. G. (2005). The atypical resistance gene RPW8 recruits components of basal defence for powdery mildew resistance in Arabidopsis. Plant Journal 42: 195-110 